\title{
MELEJITKAN POTENSI ANAK DALAM KELUARGA, DITINJAU DARI PERSPEKTIF ISLAM
}

\author{
Ahmad Sarkawi \\ (UIN Sumatera Utara. Email: ahmadsarkawi@gmail.com)
}

\begin{abstract}
Pelaksanaan pendidikan yang dilakukan oleh keluarga adalah pendidikan pertama yang di tempati oleh anak. Orang tua merupakan pendidik pertama bagi anak-anak, karena dari orang tua anak mula-mula mendapatkan pendidikan. Situasi pendidikan dalam keluarga akan terwujud apabila semua pihak yang ada dalam keluarga dapat menjalin kerjasama yang baik, juga berkat pergaulan dan hubungan pengaruh mempengaruhi secara timbal balik antara orang tua dan anak. Jika iklim dalam keluarga baik dan menanamkan nilai-nilai keislaman yang lubur maka tidak dapat dipungkiri tumbuh kembang anak akan berjalan dengan optimal sehingga perkembangan potensi anak juga akan berkembang dengan baik.
\end{abstract}

Kata Kunci: Melejitkan, Potensi, anak, Perspektif

\section{PENDAHULUAN}

Pernikahan adalah bentuk yang sempurna dari kehidupan berkeluarga. Allah menciptakan laki-laki dan perempuan agar bisa hidup berdampingan, dalam pertalian keluarga yang bahagia, sejahtera, hidup tenteram dan penuh kasih sayang. Dalam Islam disebut keluarga sakinah mawaddah warahmah.

Ajaran Islam telah memberikan garisan tentang kriteria dalam pemilihan jodoh. Islam telah memberikan norma-norma atau nilai - nilai yang harus dianut. Seperti diungkapkan oleh hadist Nabi Muhammad yaitu :

$$
\begin{aligned}
& \text { عن أبى هريرة رضى الله عنه عن النبى صلى الله } \\
& \text { عليه وسلم قال تنكح المرأة لأربع لمالها والحسبها } \\
& \text { والجماها ولدينها فاظفر بذات الدين تريت يداك } \\
& \text { :رواه البخاري }
\end{aligned}
$$

Dari Abu Hurairah, Rasulullah SAW bersabda wanita dinikahi karena empat hal (pertimbangan) karena kekayaan, karena kedudukannya, karena kecantikannya dank arena kekuatan agamanya engkau pasti beruntung. (H.R. Bukhari)
Hadis di atas mengajarkan pedoman dalam memilih jodoh untuk melangsungkan perkawinan. Hal ini bertujuan untuk mencapai sebuah keluarga sejahtera dan penuh kasih sayang. Keluarga sakinah mawaddah wa rahmah.

Keluarga sakinah mawadah warahmah merupakan unsur kebahagiaan hidup. Hubungan yang harmonis akan tercapai manakala dalam keluarga dibina sikap saling menghormati. Satu sama lain memberikan penghargaan sesuai dengan status dan kedudukan masing-masing (Thohari Musnamar, 1992: 65)

Sebuah keluarga yang tidak ada rasa kasih sayang dan saling menghargai akan menimbulkan ketidakharmonisan. Ini dapat dilihat dalam kehidupan, di mana anak-anak menderita bukan karena kurang pemeliharaan, makan, pakaian, jajan dan tempat tinggal. Tapi, mereka menderita karena melihat ketidakharmonisan dalam keluarga. Antara suami istri terjalin keharmonisan dan saling menghargai. keharmonisan tersebut akan terlihat, sehingga berdampak baik terhadap perkembangan potensi anak. 
Gambaran di atas dapat diketahui bahwa keadaan keluarga, (ibu dan bapak) sangat menentukan perkembangan jiwa dan sikap seorang anak dalam keluarga sampai pada tahap perkembangan potensi anak. sikap dan perlakuan orang tua terhadap anak semenjak dalam kandungan sampai tingkat kedewasaan akan berpengaruh, apabila orang tua dapat bersikap baik maka baiklah kehidupan anaknya, tapi sebaliknya apabila orang tua tidak bersikap baik sebagaimana ketentuan ajaran agama maka akan berakibat terhadap pertumbuhan dan perkembangan potensi anak (Abdullah Nashih Ulwah, 1981: 56)

Setiap anggota keluarga berkewajiban dan bertanggung jawab terhadap pembinaan keluarga dalam kehidupan dunia maupun akhirat. sehingga tercapai kebahagian, sebagaimana Allah berfirman dalam surat al-Tahrim ayat 6 :

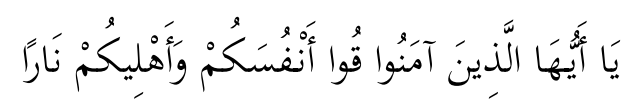

Hai orang-orang yang beriman peliharalah dirimu dan keluargamu dari api neraka. (Q.S. al-Tahrim ayat 6)

Untuk mewujudkan keluarga bahagia dan sejahtera dibutuhkan bebera faktor penting diantaranya faktor keharmonisan dalam keluarga besar. Faktor orang tua yang tidak baik, punya resiko besar terhadap keutuhan keluarga tersebut, lebihlebih terhadap tumbuh kembangnya potensi anak.

Anak akan tumbuh menjadi nakal dan berlanjut kepada tindak kejahatan atau kriminal, serta mengganggu keamanan masyarakat. Anakanak seperti ini pada umumnya dibesarkan dalam keluarga yang tidak harmonis. Menghindari konflik yang terjadi dalam keluarga, hendaknya seseorang yang sudah menikah menyadari, bahwa sudah hadir amanah baru yaitu amanah pernikahan yang bertujuan menjaga keharmonisan dan kerukunan keluarga.

Dadang Hawari (2012) mengungkapkan perihal pola keluarga, bahwa Keluarga yang tidak sehat dan tidak membawa kebahagian rumah tangga, akan berakibat tidak baik terhadap tumbuh kembangnya anak. Sebagai orang tua seharusnya mengembangkan serta mengarahkan anak ke arah yang lebih baik.

Pelaksanaan pendidikan yang dilakukan oleh keluarga adalah pendidikan pertama yang di tempati oleh anak. Orang tua merupakan pendidik pertama bagi anak-anak, karena dari orang tua anak mula-mula mendapatkan pendidikan. Situasi pendidikan dalam keluarga akan terwujud apabila semua pihak yang ada dalam keluarga dapat menjalin kerjasama yang baik, juga berkat pergaulan dan hubungan pengaruh mempengaruhi secara timbal balik antara orang tua dan anak.

Dalam ajaran Islam dinyatakan bahwa anak dilahirkan dalam keaadan fitrah. Orang tua sebagai seorang pendidik pertama akan menentukan kemana arah pendidikan anak. Sebagaimana firman Allah dalam surat Ar-Rum ayat 30 yang berbunyi :

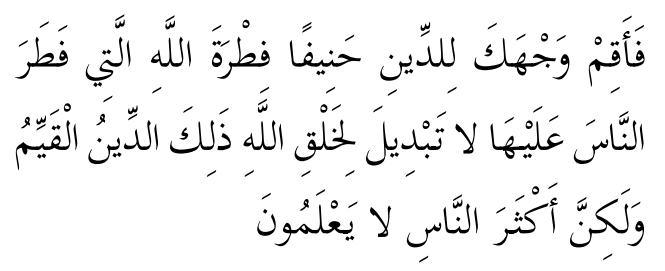

Maka hadapkanlah wajahmu dengan lurus kepada agama Allah (tetap atas) fitrah Allah yang telah menciptakan manusia menurut fitrah itu tidak ada perubahan atas fitrah Allah (itulah ) agama yang lurus tapi kebanyakan manusia tidak mengetahuinya. (ar-Rum: 30) 
Dalam hadis Nabi yang diriwayatkan oleh Abu Hurairah menjelaskan tentang fitrah manusia, berbunyi :

$$
\begin{aligned}
& \text { عن أبى هريرة رضى الله عنه يقول أن النبي } \\
& \text { صلى الله عليه وسلم يقول كل مولود يولد على } \\
& \text { الفطرة فأبواه يهودانه أو يناصرانه أو يمجسانه يعوله } \\
& \text { :رواه البخاري }
\end{aligned}
$$

Dari abi hurairah R.A. dari Rasulullah SAW, tiap-tiap anak dilabirkan dalam keadaan fitrah maka ibu bapaknyalah yang menjadikan anak itu beragama Yahudi, Nasrani atau Majusi, (H.R. Muslim)

Ayat dan hadis diatas menjelaskan bahwa setiap anak dilahirkan dalam keadaan fitrah, dalam tafsiran al- Maraghi dikatakan bahwa : Tetaplah kalian semua pada fitrah yang telah diciptakan oleh Allah, dalam diri mereka fitrah yang selalu cenderung kepada ajaran tauhid dan meyakininya. Hal itu karena ajaran tauhid itu sesuai dengan apa yang ditunjukkan akal dan membimbing kepada pemikiran yang sehat (Ahmad Mustafa al- Maraghi, 1992: 83)

Ahmad Mustafa Al-maraghi menjelaskan bahwa setiap manusia mempunyai fitrah yang cenderung kepada ajaran tauhid. kecenderungan seorang anak akan terus bertambah kuat apabila selalu dipupuk dan dibina oleh orang tua semenjak anak dilahirkan, tetapi sebaliknya fitrah yang sudah ada dalam diri anak sedikit demi sedikit akan hilang apabila tidak dibina dan dibimbing kearah yang lebih sempurna. Dapat diambil kesimpulan bahwa fitrah yang sudah ada dalam diri anak akan berkembang apabila terus dibimbing kearah yang lebih baik.
Orang tua bertanggung jawab melaksanakan pendidikan anak sesuai dengan ajaran Islam. Ajaran Islam mengajarkan cara mendidik anak, dan hal apa yang harus diperhatikan orang tua dalam mendidik anak. Pada umumnya pendidikan yang dilakukan keluarga tanpa berdasarkan pengertian lahir dari pengetahuan mendidik, tetapi secara alamiah suasana itu terwujud dengan sendirinya. secara kodrati ada tuntutan tugas dan tanggung jawab untuk mengarahkan sikap anak, yang mana orang tua berfungsi sebagai pendidik. Hal ini sesuai dengan hadis yang diriwayatkan oleh Bukhari berikut ini :

$$
\begin{aligned}
& \text { حدثنا موسى بن إسماعيل حدثنا عبد الواحد ثنا } \\
& \text { صالح الهمدانى حدثنا الشعبى أبوبردة عن أبيه } \\
& \text { قال: قال رسول الله صلى الله عليه وسلم أيما } \\
& \text { رجل كانت عنده وليدة فعلمها فأحسن تعليمها } \\
& \text { وأدابها فأحسن تلأديبها ثم اعتقادها و تزوجها }
\end{aligned}
$$

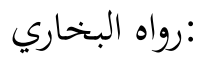

Dari Musa bin Ismail dari Abdul Wahid dari Salih bi Salih al-Hamdainy dari Sya'bi dari Abu Burdah dari bapaknya ia berkata, bersabda Rasulullah $S A W$ : setiap orang tua yang mempunyai anak maka kewajibannya adalah mengajarinya, membaguskan ajaran dan akhlaknya, membaguskan didikannya kemudian melepaskannya dan mengawinkannya( H.R. Bukhari)

Al-Qur'an mengajarkan bagaimana cara berbicara dengan anak dalam menyampaikan pelajaran sebagaimana yang terdapat dalam surat Luqman ayat 13 yang berbunyi:

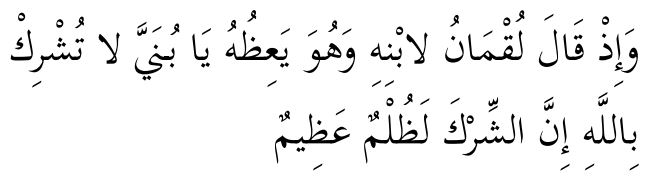


Dan ingatlah ketika Luqman berkata kepada anaknya anaknya di waktu ia memberi pelajaran padanya, wahai anakku janganlah kamu menyekutukan Allah, sesungguhnya menyekutukan Allah adalah benar-benar kezaliman yang besar (Q.S. Luqman: 13)

Ayat di atas mengajarkan kepada orang tua cara berbicara pada anak dalam menyampaikan pelajaran,diantara manfaat ayat di atas adalah: ayat ini mengungkapkan kata 'wahai anakku' artinya seorang ayah atau ibu apabila berbicara pada putra-putrinya menggunakan kata lemah lembut dan ungkapan-ungkapan lain yang disenangi anak (Husain Mazhahiri, 1999).

Tata cara pendidikan dalam keluarga akan berjalan lancar apabila tercermin nilai-nilai ajaran Islam yang dilaksanakan dalam kehidupan, baik dalam mendidik anak maupun dalam kehidupan keseharian, baik dalam mendidik anak maupun dalam membina kerukunan dalam rumah tangga. Sorang anak akan tumbuh dan berkembang potensi yang dimilikinya dengan matang apabila ia dibesarkan dalam keluarga yang sehat bahagia.

\section{METODE PENELITIAN}

Untuk melakukan pembahasan atau penelitian ini maka dalam hal ini penulis memakai metode penelitian kepustakaan (library research), yaitu serangkaian kegiatan yang berkenaan dengan metode pengumpulan data pustaka, membaca dan mencatat serta mengolah bahan penelitian, menggunakan bahan tertulis, seperti buku, jurnal, majalah, dan sebagainya (Mestika Zed, 2004).

Berdasarkan teknik analisis data, penelitian ini merpakan penelitian kualitatif. Intrepretasi dan penyajian data dilakukan melalui metode deskriptif-analitis, yaitu penyusunan data melalui teks naratif, lalu dilakukan analisis data dan bangunan teori-teori yang siap diuji kebenaranya.

\section{PEMBAHASAN}

\section{Faktor yang Mempengaruhi Potensi Anak}

Pada umumnya anak memiliki pola pertumbuhan dan perkembangan normal yang merupakan hasil interaksi banyak faktor yang mempengaruhi pertumbuhan dan perkembangan anak. Adapun faktor-faktor yang mempengaruhi kualitas tumbuh kembang potensi anak antara lain (Aliah B. Purwakania Hasan, 2008):

\section{Faktor Dalam (Internal)}

Pertama, Ras/etnik atau bangsa : Anak yang dilahirkan dari ras/bangsa Amerika, maka ia tidak memilki faktor herediter ras/bangsa Indonesia atau sebaliknya. Karakteristik yang diturunkan mempunyai pengaruh besar pada perkembangan. Jenis kelamin dan determinan keturunan lain secara kuat mmpengaruhi hasil akhir pertumbuhan dan laju perkembangan untuk mendapatkan hasil akhir tersebut. Terdapat hubungan yang besar antara orangtua dan anak dalam hal sifat seperti tinggi badan, berat badan, dan laju pertumbuhan. Kebanyakan karakter fisik, termasuk pola dan bentuk gambaran, bangun tubuh, dan ganjilan fisik, diturunkan dan dapat mempengaruhi cara pertumbuhan dan integrasi anak dengan lingkungannya.

Kedua, Hormon : Ada tiga hormon yang mempengaruhi pertumbuhan anak yaitu: Somatotropin, hormon yang mempengaruhi jumlah sel tulang, merangsang sel otak pada masa pertumbuhan. Berkurangnya hormon ini dapat menyebabkan gigantisme, hormon tiroid, mempengaruhi pertumbuhan tulang. 
Berkurangnya hormon ini dapat menyebabkan kreatinisme; Hormon gonadotropin, merangsang testosteron dan merangsang perkembangan seks laki-laki dan memproduksi spermatozoid. Sedangkan estrogen merangsang perkembangan seks sekunder wanita dan produksi sel telur, kekurangan homon gonadotropin dapat menyebabkan terhambatnya perkembangan seks.

Ketiga, Umur : Kecepatan pertumbuhan yang pesat adalah masa prenatal, tahun pertama kehidupan dan masa remaja.

Keempat, Emosi : Hubungan yang hangat dengan orang lain seperti dengan ayah, ibu, saudara, teman sebaya serta guru akan memberi pengaruh terhadap perkembangan emosi, sosial dan intelektual anak. Cara anak berinteraksi dalam keluarga akan mempengaruhi interaksi anak di luar rumah. Apabila keinginan anak tidak dapat terpenuhi sesuai dengan tahap perkembangan tertentu dapat memberi pengaruh terhadap tahap perkembangan selanjutnya. Stress adalah ketidakseimbagan antara tuntutan lingkungan dan sumber koping individu yang menggangggu ekuibrium individu tersebut. Usia anak, temperamen situasi hidup, dan status kesehatan mempengaruhi kerentanan, reaksi dan kemampuan mereka untuk mengatasi stress. Kenali tanda stress untuk membantu anak menghadapi stress sebelum stress menjadi berat.

Kelima, Jenis kelamin : fungsi reproduksi pada anak perempuan berkembang lebih cepat daripada laki-laki. Tetapi setelah melewati masa pubertas, pertumbuhan anak laki-laki akan lebih cepat.

Keenam, Genetik : adalah bawaan anak yaitu potensi anak yang akan menjadi ciri khasnya. Ada beberapa kelainan genetik yang berpengaruh pada tumbuh kembang anak seperti kerdil.

Ketujuh, Kelainan kromosom : Kelainan kromosom umumnya disertai dengan kegagalan pertumbuhan seperti pada sindroma Down's dan sindroma Turner's.

\section{Faktor Luar}

Prenatal (Sebelum Kelahiran)

Pertama, Gizi : Nutrisi ibu hamil terutama dalam trisemester akhir kehamilan akan mempengaruhipertumbuhan janin.

Kedua, Toksi/zat kimia : beberapa obatobatan dapat menyebabkan kelainan congenital.

Ketiga, Radiasi Paparan radium dan sinar rontgen dapat mengakibatkan kelainan pada janin seperti deformitas anggota gerak.

Keempat, Infeksi : Infeksi pada trimester pertama dan kedua oleh virus TORCH dapat menyebabkan kalainan pada janin, katarak, bisu tuli, retasdasi mental dam kelainan jantung.

Kelima, Kelainan imunologi : Adanya perbedaan golongan darah antara janin dan ibu sehingga ibu membentuk antibodi terhadap sel darah merah janin, kemudian melalui plasenta masuk dalam peredaran darah janin dan akan menyebabkan hemolisis yang selanjutnya mengakibatkan kerusakan jaringan otak.

Keenam, Psikologi ibu: Kehamilan yang tidak diinginkan, perlakukan salah/kekerasan mental pada ibu hamil dan lain-lain (Slameto, 2003: 48).

\section{Pascanatal (Setelah Kelahiran)}

Pertama, Gizi: untuk tumbuh kembang bayi, diperlukan zat makanan yang kuat. Nutrisi mungkin merupakan satu-satunya pengaruh paling 
pentng pada pertumbuhan. Faktor diet mengatur pertumbuhan pada semua tahap perkembangan, dan efeknya ditujukan pada cara beragam dan rumit. Selama periode pertumbuhan prenatal yang cepat, nutrisi buruk dapat memengaruhi perkembangan dari waktu impalmantasi ovum sampai kelahiran.

Kedua, Intelegensi: Pada umumnya anak yang mempunyai integensi tinggi, mempunyai perkembangan lebih baik.

Ketiga, Penyakit kronis/kelainan kongenital: tuberkolosis, anemia, kelainan jantung bawaan mengakibatkan retardasi pertumbuhan jasmani. Banyak penyakit kronik yang dikaitkan dengan berbagai tingkat kegagalan pertumbuhan adalah anomaly jantung congenital dan gangguan pernafasan seperti kistik fibrosis. Gangguan apapun yang dicirikan dengan ketidakmampuan untuk mencerna dan mengabsorbsi nutrisi tubuh akan member efek merugikan pada pertumbuhan dan perkembangan.

Keempat, Lingkukan fisis dan kimia: Lingkungan sebagai tempat anak hidup berfungsi sebagai penyedia kebutuhan dasar anak. Sanitasi lingkungan yang kurang baik, kurangnnya sinar matahari, paparan sinar radioaktif, zat kimia tertentu mempunya dampak yang negatif terhadap pertumbuhan anak. Bahaya dilikungan adalah sumber kekhawatiran pemberi asuhan kesehatan dan orang lain yang memerhatikan kesehatan dan keamanan. Cidera fisik paling sering terjadi akibat bahaya lingkungan. Anak berisiko tinggi mengalami cidera akibat residu kimia dari kehidupan modern saat inidilingkungan. Bahaya dari residu kimia ini berhubungan dengan potensi kardiogenik, efek enzimatik, dan akumulasi.
Kelima, Hubungan anak dengan orang sekitarnya. Seorang anak yang tidak dikehendaki oleh orang tuanya atau anak yang selalu merasa tertetkan, akan mengalami hambatan di dalam pertumbuhan dan perkembangannya.

Keenam, Kemisikinan selalu berkaitan dengan kekurangan makanan, kesehatan lingkungan yang jelek dan ketidaktahuan, akan menghambat pertumbuhan anak. Riset menunjukkan bahwa tingkat sosioekonomi keluarga anak mempunyai dapak signifikan pada pertumbuhan dan perkembangan. Pada semua usia anak dari keluarga kelas atas dan menengah mempunyai tinggi badan lebih dari anak dari keluarga dengan strata sosioekonomi rendah.

Ketujuh, Lingkungan Pengasuhan. Pada lingkungan pengasuhan, interaksi ibu anak sangat mempengaruhi tumbuh kembang anak. Hubungan dengan orang terdekat memainkan peran penting dalam perkembangan, terutama dalam perkembangan emosi, intelektual, dan kepribadian. Tidak hanya kualitas dan kuantitas deengan orang lain yang memberi pengaruh pada nak yang sedang berkembang, tetapi luasnya rentang kontak penting untuk pembelajaran dan perkembangan kepribadian yang sehat.

Kedelapan, Stimulasi. Pertumbuhan memerlukan rangsang/stimulasi khususnya dalam keluarga, misalnya penyediaan alat mainan, sosialisasi anak, keterlibatan ibu dan anggota keluarga lain terhadap kegiatan anak.

Kesembelian, Obat-obatan: Pemakaian kortikosteroid jangka lama akan menghamba pertumbuhan, demikian halnya dengan pemakaian obat perangsang terhadap susunan saraf yang menyebabkan terhambatnya produksi 
hormon pertumbuhan (Hidayat Aziz Alimul, 2008).

Kesepuluh, Pengaruh Media Masa: Media dapat member pengaruh besar pada perkembangan anak. Tidak diragukan lagi bahwa media member anak suatu cara untuk memperluas pengetahuan mereka tentang dunia tempat mereka hidup dan berkontibusi untuk mempersempit perbedaan antar kelas.

Kesebelas, Materi Bacaan : Buku, Koran, dan majalah adalah bentuk media masa paling tua. Materi ini berkontribusi pada kompetensi anak dalam hamper setiap arah dan juga member kesenangan.

Keduabelas, Televisi: Media dengan dampak yang paling besar pada anak menjadi salah satu agen penyosialisasi paling penting dalam kehidupan anak. Disamping menimbulkan efek tertentu mengenai perbedaan kelas dalam informasi umum dan pembendaharaan kata. Televisi memanjakan anak pada berbagai topik dan kejadian yang lebih luas dari yang mereka hadapi dalam kehidupan sehari-hari. Film yang tidak terikat erat pada kenyataan dan sering menggambarkan berbagai perilaku berbagai perilaku yang disetujui secara social mungkin member kontribusi pada sistem nilai anak dan memberikan kesempatan untuk pembelajaran sosial yang diinginkan.

Ketigabelas, Computer/Internet. Penggunaan computer baik diruang kelas dan dirumah telah mempenagruhi pembelajaran dan perkembangan dimasa kanak-kanak.Salah satu strategi yang bermanfaat menempatkan computer diruang prublik dirumah seperti dapur atau ruang keluarga agar orang tua dapat dengan mudah.
Faktor keluarga merupakan pusat pendidikan yang pertama. Faktor keluarga mencakup orang tua. Cara mendidik anak Sikap orang tua yang kurang memperhatikan pendidikan yang dibutuhkan, acuh tak acuh, tidak memperhatikan kemajuananak, bersifat otoriter, memanjakan, kejam dan mengekangakan menjadi penyebab timbulnya mental yang tidak sehatpada anak. Hal ini akan berakibat seorang anak tidak bisamengembangkan dirinya sehingga anak tersebut akanketergantungan terhadap orang tua.

Hubungan orang tua dan anak Perhatian atau penghargaan yang diberikan orang tuamerupakan faktor yang penting sekali dalam menentukankemaluan anak. Pemberian tauladan dan bimbingan dan orang tua. Suasana rumah atau keluarga. Ketentraman, kedamaian dan keharmonisan rumah tangga akan menguntungkan bagi kemajuan anak dalam beraktivitas kreatif. Hal ini dijelaskan dalam al- Qur'an surat an-Nahal ayat 78 :

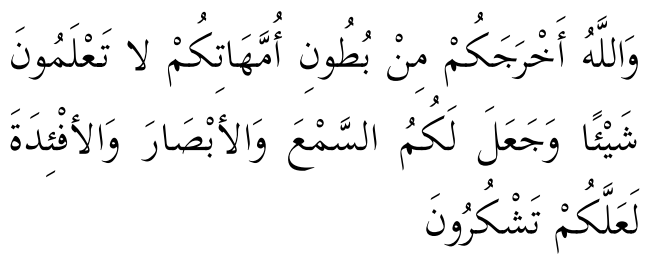

Dan Allah mengeluarkan kamu dari perut ibumu dalam keadaan tidak mengetahui sesuatu pun, dan Dia memberi kamu pendengaran, penglihatan, dan hati, agar kamu bersyukur.

Pengembangan sikap-sikap sejak dini kepada anak menghasilkan "kebiasaan-kebiasaan" baik dalam diri anak. Kebiasaan menyebabkan anak secara "spontan" menghadapi satu situasi hidup selalu berpegangan kepada norma perilaku yang dianuti. Menghadapi sesama yang terkena musibah selalu siap membantu; menghadapi 
kemungkinan meraup uang atas cara yang curang, anak tersebut akan berusaha tetap jujur dan tidak curang karena merasa bertanggung jawab kepada Allah SWT.

Sikap-sikap ini pada umumnya dikembangkan melalui mata pelajaran yang bermuatan paham dan nilainilailuhur kemanusiaan. Mata pelajaran itu adalah pendidikan Agama, budi pekerti, dahulu PMP, PPKN dan sejenisnya. Pertanyaannya adalah mengapa melalui sekian banyak jam pendidikan agama di SD (dua jam per pekan artinya minimal 80 jam per tahun, atau 480 jam selama jenjang SD) dan dilanjutkan pada jenjang-jenjang berikutnya, pendidikan Agama tidak atau kurang memberikan hasil yang diinginkan? Mengapa warga bangsa yang mengikuti sekian puluh bahkan sekian ratus jam PMP tidak nampak lebih adil secara sosial, lebih beradab secara manusia.

Relevansi ditentukan oleh bermanfaat tidaknya bekal hidup yang diberikan. Sampai saat ini kalangan guru dan pendidik masih menganuti paham tradisional. Anak yang membawa harapan adalah anak yang dinilai cerdas, dalam arti memiliki kemampuan intelektual tinggi. Penelitian longitudinal yang dibuat kalangan Harvard memberikan bukti-bukti yang meyakinkan bahwa keberhasilan di dalam hidup bukan ditentukan oleh tingginya IQ. Ada faktor lain yang lebih berpengaruh. Satu dari faktor lain itu adalah kecerdasan emosional. Kemudian ditemukan lagi beberapa "kecerdasan" lain, yang turut menentukan keberhasilan seseorang didalam kehidupan yang konkret. Apabila sekolah-sekolah ingin relevan, artinya ingin memberikan bekal hidup bagi peserta didik, maka temuan diatas harus mengubah titik berat pendidikan dan dunia persekolahan kita. Kita tetap meningkatkan kemampuan intelektual, akan tetapi kita tidak boleh berat sebelah (Sutan Surya, 2007).

Peningkatan kemampuan emosional dan kemampuan-kemampuan lain harus mendapat porsi yang seimbang. Sekarang digunakan satu skala nilai untuk "mengukur" kadar intelektual murid, padahal untuk mengukur kemampuan emosi dan lain-lain tidak ada alatnya. Di dalam raport dituliskan nilai berdasarkan daya serap (intelek!) murid. Untuk "kecerdasan" lain, yang sebenarnya lebih menentukan keberhasilan murid di dalam kehidupan, hanya ada catatan tentang kelakuan. Dalam kolom kelakuan pada umumnya ditulis dengan gampang "baik", tanpa skala nilai yang sedikit lebih akurat. Memang dunia pendidikan kita masih mendewakan kemampuan intelektual. Demi relevansi pendidikan, hal ini harus diubah. Sekolah harus memberikan perhatian serius dan meluangkan waktu dan jam pelajaran untuk mengembangkan kemampuan emosional dan sosial, kemampuan berkomunikasi dan berinteraksi, kemampuan bekerja sama dalam kelompok, dan lain-lain.

Pembinaan potensi-potensi diluar inteligensi harus dijadwalkan baik di dalam jam pelajaran, maupun melalui kegiatankegiatan ekstrakurikuler yang mengembangkan kemampuan berkomunikasi, berinteraksi, berprakarsa dan bekerjasama dalam kelompok. Bekal hidup yang penting tetapi kurang diperhatikan disekolah-sekolah adalah sikap-sikap hidup yang membentuk watak seseorang. Sikap sederhana, jujur, terbuka, penuh toleransi, rela berkomunikasi dan berinteraksi, ramah-tamah dan bersahabat, siap bahu-membahu didalam 
pergaulan sehari-hari, cinta yang ikhlas kepada sesama, khususnya yang kurang beruntung. Tidak hanya mementingkan diri sendiri, cinta tanah air tanpa terkungkung dalam chauvenisme yang sempit dan lain-lain, merupakan sikap-sikap yang menjadi permata-permata dalam kepribadian seseorang.

Kognisi atau intelektual dapat diartikan sebagai kegiatan berpikir; mencari, mengelola sampai menggunakan pengetahuan. Anak yang sedang memfungsikan kognisinya akan memulai dari mengamati sesuatu, selanjutnya dicerna dan kemudian dipikirkan. Afeksi merupakan perasaan yang dimiliki anak terhadap sesuatu. Seperti perasaan senang dan sedih, suka dan tidak suka, baik dan buruk, termasuk sikap dan akhlak (Abu Ahmadi, 2003: 182)

Psikomotor berhubungan dengan fisik, misalnya gerakan-gerakan tubuh. Anak yang memiliki psikomotor yang baik dapat melakukan gerakan-gerakan fisik dengan seimbang, terarah dan gerakan tersebut memiliki tujuan yang baik.

Usaha meningkatkan kecerdasan anak harus meliputi seluruh ranah pribadi anak, yaitu ranah kognisi, afeksi dan psikomotor. Hal ini dilakukan bertujuan agar anak memperoleh keseimbangan dalam dirinya. Ketika anak cerdas namun juga memiliki kejujuran, tanggungjawab kedisiplinan serta memiliki kekuatan tubuh (fisik) yang baik.

Setiap ranah yang ada dalam diri anak dapat ditingkatkan dengan cara yang berbeda-beda. Untuk meningkatkan kemampuan kognisi anak, orang tua perlu memberi makanan berupa ilmu pengetahuan, berita dari berbagai media, bukubuku bacaan, alat permainan yang merangsang kreatifitas (seperti permainan pasir, balok kreatif, kartu imajinatif, dan sebagainya). Sedangkan untuk meningkatkan kemampuan Afeksi anak, orang tua bisa memberikan makanan berupa kasih sayang, perhatian, motivasi, ucapan-ucapan bijak dan lembut yang disampaikan pada anak. Dan untuk meningkatkan kemampuan Psikomotor anak, makanannya berupa asupan gizi 4 sehat 5 sempurna, olah raga dan aktivitas gerakan fisik yang cukup.

Saat ini bisa dikatakan tak perlu kawatir dengan pemenuhan peningkatan kemampuan kognisi dan psikomotor anak. Di sekolah anak cukup memperoleh rangsangan untuk meningkatkan pengetahuan mereka melalui mata pelajaran yang diberikan. Demikian juga kegiatan olah raga yang rutin disekolah ataupun perhatian kita terhadap gizi anak akan memenuhi kebutuhan peningkatan kemampuan psikomotor anak. Walau demikian bukan berarti di rumah kita tidak perlu lagi memberikan pengetahuan atau perhatian terhadap perkembangan fisik.

Perlu diperhatikan pada saat ini adalah sentuhan afeksi pada anak-anak kita. Anak yang memiliki afeksi yang kuat berarti memiliki kepekaan atau perasaan yang kuat, ia memahami perasaan apa yang sedang ia rasakan, dan mampu memahami perasaan orang lain. Ketika ia kesal karena dijahili temannya, maka reaksi yang muncul adalah kekesalan bukan amarah atau sampai mendendam. Dan seketika itu pula ia tahu bagaimana menyikapi dirinya ketika ia sedang kesal, agar jangan sampai kekesalannya itu menyakiti temannya tadi. Misalnya dengan kekesalannya itu, ia tidak lantas marah-marah atau sampai memukul temannya, tetapi ia akan dengan lapang dada mengatakan pada temannya "Saya ga suka, kalau kamu jahilin saya!". 
Afeksi yang baik dalam diri anak juga tercermin dalam kekuatan spiritual anak. Anak yang taat pada kedua ibu bapaknya, mampu menyayangi anak yatim, mengasihi fakir miskin, mampu berserah diri pada Allah, serta taat dalam ibadah menunjukkan kecerdasan afeksi yang dimiliki anak. Karena semua aktivitas tersebut hanya dimiki oleh anak yang peka dan kuat perasaannya.

Rasulullah SAW telah memberikan contoh bagaimana mengembangkan afeksi anak, yaitu dengan memberi ciuman pada anak-anak sebagai wujud rasa sayang Beliau. Dengan demikian aktivitas mencium, membelai, memeluk anak perlu diberikan orang tua kepada anak sehari-hari. Selain itu orang tua juga bisa mengembangkan afeksi anak melalui pemberian motivasi dan keteladanan. Misalnya dengan senantiasa memberikan dorongan anak untuk berbuat baik, mendorong anak untuk memiliki akhlak terpuji maupun mendorong anak untuk senantiasa berdoa dan berserah diri pada Allah SWT (Ramayulis, 2002: 77)

Melalui keteladanan, afeksi anak juga dapat dikembangkan. Misalnya orang tua mudah memaafkan dan meminta maaf pada anaknya, tentu hal ini akan dicontoh anak. Lainnya, seperti memberi keteladanan dalam bentuk bersabar ketika mengingatkan anak yang lalai, lembut dalam tutur kata, jujur dalam berbicara, bertanggung jawab atas apa yang dipilih atau dilakukan. Semua hal tersebut akan mengembangkan afeksi anak.

Hal lain yang bisa dilakukan, bisa sesekali waktu mengajak anak rihlah (jalan-jalan) ketempat yang pemandangannya indah, seperti pegunungan, sungai, daerah pedesaan yang asri dan sebagainya. Disana, anak kita sentuh afeksinya dengan mengajak mereka merenungi ciptaan Allah yang sangat indah yang wajib disyukuri, merenungi bagaimana ketika bencana tiba-tiba terjadi maka pertolongan Allah SWT yang harus kita pinta untuk pertama kali. Demikianlah beberapa hal yang dapat kita lakukan sebagai orang tua untuk meningkatkan kecerdasan anak. Segala usaha tetap harus dibarengi dengan do'a, kemudian berserah diri atas usaha yang telah kita lakukan.

Bermain merupakan kegiatan yang menyenangkan. Melalui bermain seorang anak dapat melakukan percobaan-percobaan tanpa merasa takut gagal karena dalam kegiatan itu merekalah yang membuat peraturan. Terdapat berbagai jenis permainan yang dapat menimbulkan aktivitas menyenangkan bagi diri seseorang. Permainan eksploratif dan imajinatif merupakan jenis permainan yang mempunyai pengaruh yang besar peda perkembangan berfikir kreatif pada seorang anak. Pada permainan eksploratif, kegiatan bermain didasari keingintahuan seseorang terhadap seseorang terhadap lingkungannya yang ditandai oleh adanya penemuan-penemuan baru. Dunia anak penuh dengan pemikiran yang imajinatif. Dalam bermain imajinatif, anak mencipta dan berkhayal dengan menggunakan dirinya, permainan-permainan atau objek-objek lain yang ada disekitarnya. Bermain bagi anak adalah esensial dan mempunyai dampak luar biasa bagi keseluruhan aspek perkembangannya.

Anak-anak yang sudah sejak kecil biasa dan senang untuk bersibuk diri secara kreatif, kelak akan tumbuh menjadi pribadi-pribadi yang kreatif. Sikap ingin tahu, suka hal-hal yang baru, 
meneliti dan menguji, kesenangan dan kepuasan yang dirasakan dari mencipta sesuatu sendiri, merasa tertantang untuk memecahkan masalahmasalah rumit, sikap ini akan dibawa sampai masa dewasa. Taman Kanak-kanak merupakan lembaga pendidikan yang pertama kali ditemui anak setelah ia mempunyai kesempatan keluar dari lingkungannya yang pertama yaitu bersama orang tuanya di dalam keluarga. Sementara itu orang tua ingin mengembangkan semaksimal. Untuk kepentingan ini, diperlukan adanya sarana pembelajaran (media) yang efektif, metode pembelajaran yang praktis dan memberi pembelajaran (orang tua atau guru) yang inovatif (Mohammad sholeh Y.A. Ichron, 1996: 110).

Sangat disayangkan belakangan ini pelaksanaan dari kurikulum Taman Kanakkanak sangat kaku, ditambahnya lagi adanya tren bahwa Taman Kanak-kanak yang baik adalah yang memiliki kegiatan kurikuler yang padat ditambah dengan kegiatan ekstrakurikuler yang juga padat. Betul bahwa kurikulum perlu dilaksanakan dan diperkaya, namun seharusnya dilakukan dengan meletakkan anak sebagai sentral dalam pendidikan itu sendiri, agar potensi dasar mereka yaitu kreatifitas dan imajinasinya dapat berkembang dengan baik. Suatu kenyataan bahwa sampai sekarang sarana pembelajaran di Taman Kanak-kanak belum ada yang memadai dalam arti menyangkut pengembangan potensi. Kalaupun ada, sarana tersebut merupakan bagian yang terpotong-potong atau sekedar alat peraga atau berupa lembar kegiatan anak yang semuanya berbentuk parsial. Padahal, anak dalam pengembangan potensinya yang meliputi pengembangan otak kiri dan otak kanan secara seimbang memerlukan sarana yang benar-benar dirancang dan ditampilkan secara efektif.

Sedangkan dengan metode pembelajaran yang selama ini berlaku, kreatifitas anak sering diintervensi oleh para guru. Di Taman Kanakkanak yang terutama dilatih adalah penerimaan pengetahuan, ingatan dan penalaran saja. Anakanak pun menjadi robot. Padahal dengan kreatifitas seorang anak dapat mewujudkan dirinya, dan perwujudan diri merupakan kebutuhan pokok pada tingkat tertinggi dalam kehidupan manusia.

Selain itu, ada hal lain yang tak kalah pentingnya yang selama ini tersisihkan dari pendidikan anak, yaitu muatan keagamaan (akidah, ibadah, muamalah) yang seharusnya terintegrasi dengan muatan kurikuler. Padahal, anak adalah calon penguasa bumi (khalifatullah fil ardhi) terdapat dalam al-Qur'an surat Al Baqoroh ayat 30 :

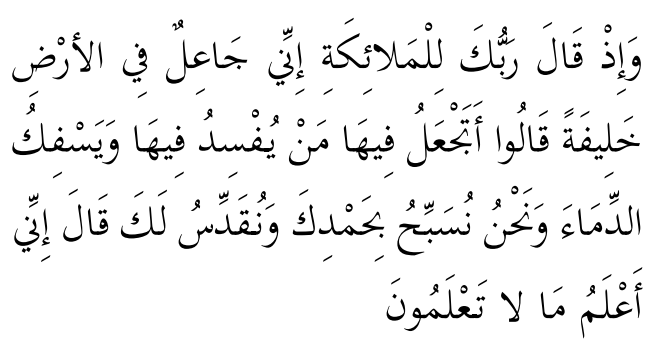

Ingatlah ketika Tuhanmu berfirman kepada para malaikat: "Sesungguhnya Aku hendak menjadikan seorang khalifah di muka bumi." mereka berkata: "Mengapa Engkau hendak menjadikan (khalifah) di bumi itu orang yang akan membuat kerusakan padanya dan menumpahkan darah, padahal kami senantiasa bertasbih dengan memuji Engkau dan mensucikan Engkau?" Tuhan berfirman: "Sesungguhnya Aku mengetahui apa yang tidak kamu ketahui."

Persiapan ke arah itu sudah seharusnya dilakukan sejak dini. Dengan tersisihnya pendidikan keagamaan itu, anak tidak memiliki landasan kuat dalam menghadapi perubahan dunia. Padahal Allah SWT tidak akan mengubah 
nasib suatu kaum jika bukan kaum itu sendiri yang mengubahnya. Pengembangan potensi dasar anak sangat perlu dilandasi dengan warna dan rasa religius agar pada akhirnya dapat ditampilkan pribadi-pribadi yang berakhlak mulia serta kreatif imajinatif illahiah. Sosok pribadi yang berguna bagi dirinya maupun agama dan bangsa. Dengan demikian diperlukan adanya sarana yang mengembangkan kreatifitas dan imajinasi serta penuh dengan nuansa agama yang masih belum kita temukan secara memadai.

Model Sistem Pembelajaran Kreatif Imajinatif adalah model pembelajaran yang memberikan rangsangan secara seimbang antara otak kiri dan otak kanan sehingga potensi dasar anak terutama kreativitas dan imajinasinya dapat berkembang secara seimbang dengan memberikan sentuhansentuhan Islami pada kognisi, afeksi dan psikomotor anak. Rangsangan-rangsangan dan sentuhan tersebut disajikan dalam pembinaan akidah, ibadah dan muamalah yang disampaikan dengan cara yang mengasyikkan sehingga anak akan merasakan kenikmatan hidup beragama. Sarana yang dipersiapkan bagi Model Sistem Pembelajaran Kreatif Imajinatif di TK disusun berdasarkan Kurikulum, psikologi perkembangan anak dan konsep pembelajaran kreatif imajinatif yang diintegrasikan dengan materi agama dan kemampuan dasar anak.

Orang tua memiliki kewajiban untuk membentuk generasi pengubah peradaban. Salah satu caranya adalah dengan mengembangkan kreatifitas anak-anak. Berdasarkan ajaran Islam, tanggung jawab pendidikan, pembentukan kualitas, dan kepribadian anak merupakan tanggung jawab kedua orang tua.
Dalam sebuah hadits Rasulullah bersabda :

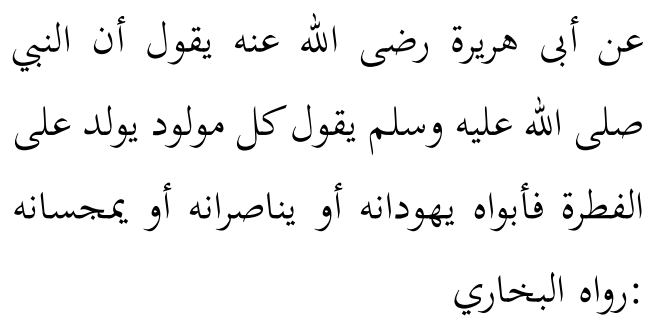

Dari abi hurairah R.A. dari Rasulullah SAW, tiap-tiap anak dilahirkan dalam keadaan fitrah maka ibu bapaknyalah yang menjadikan anak itu beragama Yahudi, Nasrani atau Majusi, (H.R. Muslim)

Ciri utama suatu keluarga tradisional dalam mendidik anak adalah berpegang teguh pada pengalaman pribadi. Membiarkan anak berkembang sendiri, tidak memberi rangsangan kognisi dan meyakini faktor keturunan paling berperan dalam pembentukan kepribadian intelegensia. Dengan pola asuh seperti ini anak umumnya tampak kurang cerdas dibanding anakanak keluarga modern dan keluarga ambivales (modernis tradisional).

Berikan kebebasan kepada anak untuk berkreasi dan mengekspresikan diri. Kebebasan disini lebih pada adanya jaminan penghargaan terhadap setiap kreasi anak. Penghargaan adalah bukti adanya dukungan psikologis orangtua yang dapat menghadirkan rasa aman dalam diri anak. Adanya rasa aman membuat anak sanggup mengkontrol rasa takutnya (takut salah, takut dimarahi, takut mencoba, dsb) yang oleh para ahli disebutkan sebagai penghalang utama kreatifitas. Penerapan disiplin sejak dini pada anak bertujuan untuk melatih tanggungjawabnya, bukan untuk memandulkan kreativitasnya.

Tanggung jawab merupakan awal pengembangan kreatifitas. Kreatifitas bukan hanya 
terkait dengan dinamika fisik tapi juga situasi mental. Pada tahap tertentu seorang yang kreatif biasanya energik, tapi tidak selalu demikian. Kreativitas itu dimulai dengan berimajinasi dalam rangka berpikir mencari solusi. Tidak ada orang kreatif yang tidak suka merenung. Orang tua dapat mendorong anak untuk belajar melakukan imajinasi, merangkai gagasan dan pikiran serta mengolah ide-ide.

Orang tua dapat mengelola potensi anak dengan memberinya keteladanan. Jangan biarkan anak menjumpai hal yang kontradiktif antara pernyataan verbal dan realita. Hal penting lainnya dalam pengelolaan potensi anak adalah pewadahan. Orangtua harus siap mewadai setiap bentuk kreatifitas anak dengan cara yang benar (Sal Severe, 2005: 8).

Dalam banyak kasus ditemui orangtua yang cerdas, kreatif namun otoriter sehingga anak tidak kreatif. Orangtua cenderung membandingkan hasil karya anak dengan kesuksesan dirinya. Anak hidup dalam bayang-bayang orangtua. Jadi pewadahan adalah kemampuan jiwa atau mentalitas orangtua untuk rajin mendengarkan, mau mengalah, mau mendukung, dan mau membiayai. Orangtua yang kreatif memiliki peluang besar untuk melahirkan anak kreatif, karena ia menggunakan cara-cara kreatif dalam berinteraksi dengan anak. Kreatif bisa ketika sedang mengajar, memberikan makanan, menyelesaikan konflik anak, mensosialisasikan anak, bermain dengan anak dan lain-lain.

Sehubungan dengan pendidikan nilai sangat penting peran keluarga. Diatas dikatakan bahwa pendidikan nilai selalu berpangkal tolak dari pengalaman dan mengarah kepada pengamalan. Nah, tanpa mengucap banyak kata dan membeberkan seluk beluk ajaran dan teori, didalam keluarga terjadi secara spontan pengalaman-pengalaman bersama, yang menggugah bukan saja nalar, ingatan, perasaaan dan kehendak manusia. Pengalaman bersama dibagi dan dikaji serta ditafsir bersama.

Nilai yang terkandung didalam pengalaman, diresapi, dihayati dan diamalkan bersama. Didalam keluarga kesabaran, sikap ramah, tenggang-rasa, dan lain-lain tidak diajarkan dengan katakata, tetapi dengan teladan, dengan pengamalan yang diperoleh dalam kehidupan kehidupan keluarga sehari-hari. Pengalaman membuka mata orang, dan pengalaman mengajak orang untuk bertindak. Dari seorang Ibu yang serba sabar, Ayah dan anakanak belajar menghargai kesabaran dan berusaha untuk juga sabar. Dari seorang Ayah yang tegas dalam pendirian tetapi supel dalam menerapkan pendidikan, anak-anak belajar memiliki pendirian tetapi bijaksana dalam menerapkan pendidikan tersebut. Tentu saja pengalaman dan pengamalan paham dan nilai di dalam keluarga mengandaikan keluarga itu benarbenar memiliki, dan berpegang teguh kepada paham dan nilai tertentu. Kecuali itu harus ada di iklim yang serasi antara anggota keluarga. Ada saling memberi dan menerima, saling menghormati dan melayani, dan yang paling penting ada komunikasi timbal balik yang enak didalam suasana keakraban keluarga.

Sayang pola hidup keluarga-keluarga modern yang anggotanya memiliki kesibukkan masingmasing sering tidak menunjang iklim yang dibutuhkan untuk dapat berkomunikasi dan berinteraksi. Bila ingin memelihara suasana keakraban, dimana ada interaksi dan komunikasi, 
keluarga-keluarga harus bersedia menyusun jadwal, meluangkan untuk bersama-sama melakukan, menghayati, mengamalkan bahkan menikmati sesuatu. Di dalam kebersamaan paham dan nilai dipertukarkan, dihayati dan diamalkan. Karena kesibukkan, orang tua sering menyerahkan seluruh pendidikan anak ke tangan para pendidik dan pengasuh disekolah. Hal ini tidak tepat. Tugas mendidik, apalagi membina paham dan nilai menjadi sikap, kepribadian dan watak merupakan tugas orang yang sudah melahirkan anak, dengan kata lain tugas orang tua.

Tidak semua tugas pendidikan dapat diemban dengan baik oleh orang tua. Untuk itu diciptakan lembaga-lembaga pendidikan. Akan tetapi, tidak boleh orang tua "lepas tangan" seluruhnya dalam urusan membesarkan dan mendewasakan anak. Kerja sama dengan pihak sekolah oleh lembaga pendidikan sangat baik dan dianjurkan, akan tetapi tidak boleh seluruh tugas mendidik dilimpahkan kepada sekolah/ lembaga pendidikan.

\section{DAFTAR PUSTAKA}

Ahmadi, Abu. (2003). Psikologi Umum. Jakarta: PT. Rineka Cipta.

Aziz Alimul, Hidayat. (2008). Pengantar Ilmu Kesehatan Anak untuk Pendidikan Kebidanan, Jakarta: Salemba Medika.

Bin Hambal, Ahmad. (tt). Musnad Ahmad bin Hambal. Jilid II. Beirut: Dar al-Fikr.

Bukhari, Imam. (1981). Shahiah Bukhari. Beirut: Dar al Fikr.

Hawari, Dadang. (1997). Al-Qur'an Ilmu Kedokteran Jiwa dan Kesehatan Jiwa. Jakarta: Dana Bhakti Prima Yasa.
Mazhahiri, Husain. (1999). Pintar Mendidik Anak. Terjemah. Segaf Abdillah Segaf \& Miqdad Turkan. Tarbiyyah ath-thifl fiarru’yah al-Islamiya. Jakarta: Lintere.

Nashih Ulwah, Abdullah. (1981). Pedoman Pendidikan Anak dalam Islam. Semarang: Asy-syifa.

Purwakania Hasan, Aliah B. (2008). Psikologi Perkembangan Islami. Jakarta: PT. Raja Grafindo Persada.

Ramayulis. (2002). Pengantar Psikologi Agama. Jakarta Pusat: Kalam Mulia.

Severe, Sal. (2005). Bagaimana Bersikap pada Anak agar Anak Bersikap Baik Berdasarkan Kisah-Kisah dari Para Orang Tua. Jakarta: PT. Gramedia Pustaka Utama.

Sholeh Y.A. Ichron, Mohammad. (1996). Identifikasi dan Pendidikan Dini Anak Berbakat, Surakarta: Departemen Pendidikan dan Kebudayaan. Direktorat Jendral Pendidikan Tinggi.

Slameto. (2003). Belajar dan Faktor-faktor yang Mempengaruhinya. Jakarta: PT.Rineka Cipta.

Surya, Sutan. (2007). Melejitkan Multiple Intelligience Anak Sejak Dini. Yogyakarta: C.V Andi Offset.

Zed, Mestika. (2004). Metode Penelitian Kepustakaan. Jakarta: Yayasan Obor Indonesia. 